\title{
Nutrient-specific compensatory feeding in a mammalian carnivore, the mink, Neovison vison
}

\author{
Kim Jensen ${ }^{1,2_{*}} \dagger$, Stephen J. Simpson ${ }^{3}$, Vivi H. Nielsen ${ }^{4}$, John Hunt ${ }^{5}$, David Raubenheimer ${ }^{6}$ and \\ David Mayntz ${ }^{2,4}$ \\ ${ }^{1}$ Department of Zoology, University of Oxford, South Parks Road, Oxford OX1 3PS, UK \\ ${ }^{2}$ Department of Bioscience, Ecology and Genetics, Aarbus University, 8000 Aarbus C, Denmark \\ ${ }^{3}$ School of Biological Sciences and the Charles Perkins Centre, University of Sydney, Sydney, NSW 2006, Australia \\ ${ }^{4}$ Department of Genetics and Biotechnology, Danish Centre for Food and Agriculture, Aarhus University, \\ Research Centre Foulum, 8830 Tjele, Denmark \\ ${ }^{5}$ Centre for Ecology and Conservation, College of Life and Environmental Sciences, University of Exeter, \\ Cornwall Campus, Penryn TR10 9EZ, UK \\ ${ }^{6}$ School of Biological Sciences, the Charles Perkins Centre and the Faculty of Veterinary Science, University of Sydney, \\ Sydney, NSW 2006, Australia
}

(Submitted 3 November 2013 - Final revision received 8 February 2014 - Accepted 22 February 2014 - First published online 20 August 2014)

\begin{abstract}
Balancing of macronutrient intake has only recently been demonstrated in predators. In particular, the ability to regulate carbohydrate intake is little studied in obligate carnivores, as carbohydrate is present at very low concentrations in prey animal tissue. In the present study, we determined whether American mink (Neovison vison) would compensate for dietary nutritional imbalances by foraging for complementary macronutrients (protein, lipid and carbohydrate) when subsequently given a dietary choice. We used three food pairings, within which two macronutrients differed relative to each other (high $v$. low concentration), while the third was kept at a constant level. The mink were first restricted to a single nutritionally imbalanced food for $7 \mathrm{~d}$ and then given a free choice to feed from the same food or a nutritionally complementary food for three consecutive days. When restricted to nutritionally imbalanced foods, the mink were willing to overingest protein only to a certain level ('ceiling'). When subsequently given a choice, the mink compensated for the period of nutritional imbalance by selecting the nutritionally complementary food in the food choice pairing. Notably, this rebalancing occurred for all the three macronutrients, including carbohydrate, which is particularly interesting as carbohydrate is not a major macronutrient for obligate carnivores in nature. However, there was also a ceiling to carbohydrate intake, as has been demonstrated previously in domestic cats. The results of the present study show that mink regulate their intake of all the three macronutrients within limits imposed by ceilings on protein and carbohydrate intake and that they will compensate for a period of nutritional imbalance by subsequently selecting nutritionally complementary foods.
\end{abstract}

Key words: Carnivore nutrition: Diet self-selection: Geometric Framework: Macronutrient balancing: Mustelidae: Predators: Protein $v$. non-protein energy

Nutrient balancing in herbivorous and omnivorous animals is well known ${ }^{(1-9)}$, but the evidence that predators balance their intake of specific nutrients is much more recent ${ }^{(10-16)}$. The previously widespread assumption that predators do not exhibit nutrient balancing has partly been predicated on a narrower range of nutrient compositions in prey than in the food sources of herbivores and omnivores and partly on the premise that predators are typically food limited ${ }^{(17,18)}$.

In nature, available prey may vary markedly not only in abundance but also in nutrient composition across species and seasons ${ }^{(19,20)}$, and some mammalian predators have been reported to feed selectively among their prey to maximise their energy intake ${ }^{(21,22)}$. Similarly, two marsupial predators have been found to selectively consume the body parts of their prey containing the highest density of lipid ${ }^{(23)}$. However, comparison of carnivore energy requirements with prey availability suggests that prey are often present in surplus and carnivores are therefore not energy limited across the seasons ${ }^{(24,25)}$. This indicates that carnivores do not always have to forage to maximise their energy intake, but often

*Corresponding author: K. Jensen, fax +1 919515 7746, email kjensen@ncsu.edu

†Present address: Department of Entomology, North Carolina State University, Raleigh, NC 27 695-7613, USA. 
have the chance to balance their intake of other food components from various prey species or prey body parts.

In addition to experimental evidence that piscivorous fish balance their intake of all the three macronutrients ${ }^{(26,27)}$, it has recently been shown that both the domestic cat (Felis catus) and dog (Canis lupus familiaris) regulate the macronutrient balance of their diet when given the opportunity to self-select among complementary foods ${ }^{(13,16)}$. It has previously been shown that captive American mink (Neovison vison) regulate their intake of protein and lipid to an intake target $^{(12)}$, but whether they have the capacity to also regulate their intake of carbohydrate and to compensate for previous nutritional imbalances has not been studied.

Wild mink primarily prey on small vertebrates ${ }^{(28-32)}$. The nutrient content in small vertebrates mainly consists of protein and lipid, with carbohydrate being present at very low concentrations $^{(32,33)}$. Thus, lipid and protein are the macronutrients that obligate carnivores would be expected to regulate. Indeed, evidence from cats indicates a low tolerance for dietary carbohydrate, such that when restricted to carbohydrate-rich foods they undereat protein and lipid to avoid a carbohydrate surplus ${ }^{(13)}$. Nevertheless, the physiological pathways for utilising carbohydrate are functional in both mink and cats ${ }^{(32)}$, and carbohydrate is included at relatively high amounts in both standard farmed mink diets and commercial cat foods to reduce economic $\operatorname{cost}^{(12,13,34)}$. Furthermore, occasional insect prey may contain significant amounts of carbohydrate $e^{(35)}$

In the present study, we used the Geometric Framework for Nutrition $^{(36)}$ to measure the regulatory responses of mink to variation in the dietary contents of protein, lipid and carbohydrate. In the first phase of the experiment, we determined how mink resolve the trade-off between overingesting some macronutrients and underingesting others when restricted to nutritionally imbalanced diets. In the second phase, we provided the mink with a choice of complementary foods and determined whether they would feed selectively to redress the imbalances accrued during the previous phase. The results of the present study show that mink respond to nutritional imbalances involving all the three macronutrients and forage selectively for deficient nutrients when given a choice.

\section{Experimental methods}

\section{Animals and housing}

The present experiment was carried out in the mink farm at Research Centre Foulum near Viborg in Denmark from 5th to 18th August 2010. The mink had been farmed for more than eighty generations. From a stock population of about 2000 mink of the colour type standard brown, 120 males aged 98-109d were selected for the experiment. The mink were housed individually in standard wired mesh cages $(30 \times 45 \mathrm{~cm}$ wide and $90 \mathrm{~cm}$ high) in an open farm shed. Temperature and lighting fluctuated with external conditions. The mink had free access to drinking-water and a closed nest furred with straw. They were reared on a standard farm diet until the start of the experiment. Each mink was weighed to the nearest $10 \mathrm{~g}$ the day before the start of the experiment. All procedures were approved by the Danish Animal Experiments Inspectorate.

\section{Experimental foods and feeding procedure}

A total of six foods varying in protein, lipid and carbohydrate contents were prepared by varying the mixing ratios of ingredients normally used for preparing unpelleted farmed mink diets (Table 1). In three food pairings, the content of one of the three macronutrients was kept constant in both foods, while the content of the other two macronutrients varied relative to each other (Table 1). The nutrient ratios of the foods were selected to achieve an appropriate spread around the regulated intake point previously indicated for mink and the composition of a standard farm food ${ }^{(12)}$ while keeping energy content per unit dry mass as constant as possible across the foods. Furthermore, carbohydrate content had to be kept at fairly low levels to ensure that the foods were palatable to the mink. As the ingredients differed in water content and level of water binding, different amounts of water were used for food preparation to obtain foods of similar texture (Table 1).

Foods were stored at $-18^{\circ} \mathrm{C}$ for up to 1 month and defrosted at $5^{\circ} \mathrm{C}$ for $12-18 \mathrm{~h}$ before use. Uneaten remains were collected and replaced with fresh food every morning. As in standard farming conditions, unpelleted foods were placed on top of the mink cage, allowing the mink to feed through the cage mesh. The water content of foods was titrated such that they were readily ingested and yet not so friable that they fell through the mesh. At each of the three choice feedings, we randomly chose which of the two foods was to be placed on either side of each cage. A felt mat placed under the cages allowed liquids but not food remains to pass through. This gave the mink another chance to eat the spilled food and permitted easy recollection and weighing of any uneaten spillage, which was minimal. Faeces were rarely left on the felt mat and were separated from the spilled food before collection.

\section{Experimental design}

In the initial stage of the experiment, the mink were allocated to one of the three dietary treatment groups ( $n 40$ mink per group) where they were provided access to both foods in one of the three food pairings (Table 1). This ensured that the mink had access to both foods in the food pair before the same pair of foods was again provided during the choice feeding period. Furthermore, it ensured that the mink had the chance to balance their macronutrient intake before the following no-choice feeding period. After $3 \mathrm{~d}$ of access to both foods, each group of mink was split into two subgroups ( $n$ 20) where the mink in each subgroup were provided only one of the two foods in the food pair for $7 \mathrm{~d}$. During the no-choice feeding period, one mink receiving the 48:42:10 food died due to an internal infection and was excluded from the analysis. To determine whether the mink would compensate for nutritional imbalances during the no-choice feeding period when given the opportunity to select their diet, both foods in the food pairs were again 
Table 1. Ingredients, dry masses, digestible nutrient contents and metabolisable energy contents of the six foods used in the experiment ${ }^{\star}$

\begin{tabular}{|c|c|c|c|c|c|c|}
\hline & \multicolumn{6}{|c|}{ Metabolisable energy distribution (\%P:\%L:\%C) } \\
\hline & \multicolumn{2}{|c|}{$P v . L$} & \multicolumn{2}{|c|}{$\mathrm{P} v . \mathrm{C}$} & \multicolumn{2}{|c|}{ L v. C } \\
\hline & $42: 46: 12$ & $26: 62: 12$ & $48: 42: 10$ & $36: 42: 22$ & $35: 55: 10$ & $35: 45: 20$ \\
\hline \multicolumn{7}{|l|}{ Ingredients ( $\mathrm{g} / \mathrm{kg}$ fresh food) } \\
\hline Fish by-product & $446 \cdot 4$ & 383.9 & 393.9 & $295 \cdot 7$ & 363.0 & 304.9 \\
\hline Industrial fish & $103 \cdot 3$ & $88 \cdot 8$ & $160 \cdot 5$ & $120 \cdot 4$ & 155.5 & $130 \cdot 6$ \\
\hline Fishmeal & 46.9 & $39 \cdot 7$ & $42 \cdot 2$ & 31.7 & $36 \cdot 0$ & 31.9 \\
\hline Poultry by-product & $80 \cdot 6$ & $69 \cdot 4$ & 168.8 & $126 \cdot 8$ & 155.5 & $130 \cdot 6$ \\
\hline $\mathrm{Hb}$ meal & $24 \cdot 2$ & $20 \cdot 8$ & $16 \cdot 9$ & $12 \cdot 7$ & $15 \cdot 2$ & $12 \cdot 8$ \\
\hline Heat-treated wheat & 40.9 & 60.5 & $27 \cdot 7$ & $70 \cdot 6$ & $36 \cdot 0$ & $67 \cdot 1$ \\
\hline Heat-treated barley & 40.9 & 60.5 & $27 \cdot 7$ & $70 \cdot 6$ & $36 \cdot 0$ & $67 \cdot 1$ \\
\hline Maize gluten & $24 \cdot 2$ & $20 \cdot 8$ & $16 \cdot 9$ & $12 \cdot 7$ & $15 \cdot 2$ & $12 \cdot 8$ \\
\hline Potato protein & $24 \cdot 2$ & $20 \cdot 8$ & $16 \cdot 9$ & $12 \cdot 7$ & $12 \cdot 9$ & $10 \cdot 9$ \\
\hline Soya bean oil & $38 \cdot 1$ & $95 \cdot 7$ & $14 \cdot 3$ & $23 \cdot 8$ & 45.4 & $28 \cdot 1$ \\
\hline Lard & $19 \cdot 2$ & 47.9 & $7 \cdot 1$ & 11.9 & $22 \cdot 7$ & 14.0 \\
\hline Vitamin and mineral mixture $†$ & 0.2 & 0.2 & 0.2 & 0.2 & 0.2 & 0.2 \\
\hline Water & 110.9 & $90 \cdot 8$ & $106 \cdot 9$ & $210 \cdot 2$ & $106 \cdot 5$ & $188 \cdot 9$ \\
\hline Dry mass ( $\mathrm{g} / \mathrm{kg}$ fresh food) & $378 \cdot 1$ & 434.4 & $340 \cdot 9$ & 348.5 & 362.9 & $357 \cdot 6$ \\
\hline \multicolumn{7}{|l|}{ Nutrient contents ( $\mathrm{g} / \mathrm{kg}$ dry food) } \\
\hline Digestible P & 414.9 & $300 \cdot 7$ & $453 \cdot 3$ & 338.9 & 374.2 & $338 \cdot 2$ \\
\hline Digestible L & $216 \cdot 2$ & $340 \cdot 4$ & $188 \cdot 1$ & 187.6 & $278 \cdot 1$ & 204.9 \\
\hline Digestible C & $127 \cdot 5$ & $148 \cdot 7$ & $101 \cdot 2$ & $221 \cdot 2$ & $113 \cdot 7$ & $207 \cdot 8$ \\
\hline \multicolumn{7}{|l|}{ Energy contents (MJ/kg dry food) } \\
\hline Digestible $P$ & $7 \cdot 8$ & $5 \cdot 7$ & 8.5 & $6 \cdot 4$ & $7 \cdot 0$ & 6.4 \\
\hline Digestible L & 8.6 & 13.5 & 7.5 & 7.5 & $11 \cdot 1$ & $8 \cdot 1$ \\
\hline Digestible C & $2 \cdot 2$ & 2.6 & 1.8 & 3.9 & $2 \cdot 0$ & $3 \cdot 7$ \\
\hline Total metabolisable energy & $18 \cdot 6$ & $21 \cdot 8$ & $17 \cdot 8$ & $17 \cdot 7$ & $20 \cdot 1$ & $18 \cdot 2$ \\
\hline \multicolumn{7}{|c|}{$\begin{array}{l}\text { \%P, percentage protein; \%L, percentage lipid; \%C, percentage carbohydrate. } \\
\text { *The contents and distributions of metabolisable energy and digestible nutrients were estimated using AgroSoft WinOpti } 2010 \text { from the } \\
\text { values of the ingredients provided by the suppliers. Different amounts of water were used for food preparation to obtain foods of a } \\
\text { similar texture. } \\
\text { †Contained per kg: } 1050000 \mathrm{mg} \text { vitamin } \mathrm{A} ; 8750 \mathrm{mg} \text { vitamin } \mathrm{D}_{3} ; 32965 \mathrm{mg} \text { vitamin } \mathrm{E} ; 29998 \mathrm{mg} \alpha \text {-tocopherol; } 12500 \mathrm{mg} \text { vitamin } \mathrm{B}_{1} ; \\
4000 \mathrm{mg} \text { vitamin } \mathrm{B}_{2} ; 4200 \mathrm{mg} \text { vitamin } \mathrm{B}_{6} ; 20 \mathrm{mg} \text { vitamin } \mathrm{B}_{12} ; 17199 \mathrm{mg} \text { pantothenic acid; } 8000 \mathrm{mg} \text { niacin; } 75 \mathrm{mg} \text { biotin; } 346 \mathrm{mg} \text { folic } \\
\text { acid; } 60003 \mathrm{mg} \text { choline; } 24999 \mathrm{mg} \mathrm{C}_{4} \mathrm{H}_{2} \mathrm{FeO}_{4} ; 1025 \mathrm{mg} \mathrm{CuSO}_{4} ; 6237 \mathrm{mg} \mathrm{MnO} ; 12563 \mathrm{mg} \mathrm{ZnO;} 120 \mathrm{mg} \mathrm{Ca}\left(\mathrm{IO}_{3}\right)_{2} ; 200 \mathrm{mg} \mathrm{Na}_{2} \mathrm{Se} \text {; }\end{array}$} \\
\hline
\end{tabular}

provided over a subsequent period of $3 \mathrm{~d}$. The amount of all foods consumed was measured over each $24 \mathrm{~h}$ during the no-choice feeding period and the following $3 \mathrm{~d}$ of choice.

\section{Intake measurements}

Before feeding, foods were pre-weighed in a metal foil box in amounts exceeding ad libitum food intake, and the remaining food was recollected in the same metal foil box the following morning. Recollected food was stored at $-18^{\circ} \mathrm{C}$ until drying at $40^{\circ} \mathrm{C}$ for $12 \mathrm{~h}$ followed by drying for another $36 \mathrm{~h}$ at $110^{\circ} \mathrm{C}$ and weighed to the nearest $1 \mathrm{~g}$. Additionally fifteen to twenty samples of each food were weighed and dried to establish the dry mass contents of fresh foods. Dry mass intake was calculated as the difference between dry mass provided and dry mass recollected. Specific intakes of protein, lipid and carbohydrate were calculated by multiplying dry food mass intakes with the proportion of each digestible nutrient in the dry food (Table 1). Digestible nutrient and metabolisable energy contents of the foods were estimated using AgroSoft WinOpti 2010, based on the ingredient contents of the foods and values provided by the suppliers.

\section{Statistical analyses}

Effects of the no-choice food on intake during the no-choice pre-treatment period were analysed across dietary treatments using ANCOVA tests with initial mink body weight as the covariate after testing for effects of body weight on dry mass intake using linear regression. The dietary treatments were compared individually using Tukey-Kramer tests. Effects of the no-choice food on intake of the two foods in each food pair during the following choice feeding period were analysed using multivariate ANOVA tests with intake from each of the two foods as the dependent variable and no-choice diet as the independent variable. Intake from the two choice foods was analysed within the nochoice pre-treatment groups using paired $t$ tests. In all statistical tests, differences were considered to be significant if $P<0 \cdot 05$. All statistical analyses were carried out in JMP 7.0 (SAS Institute).

\section{Results}

\section{Regulation under no-choice}

Dry mass intake during the no-choice feeding period was significantly affected by mink body weight across dietary 
(A)

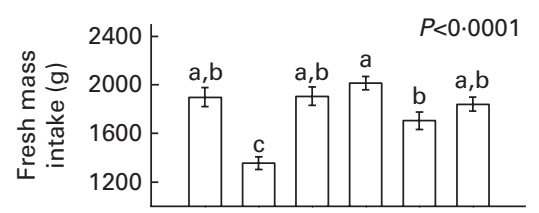

(B)

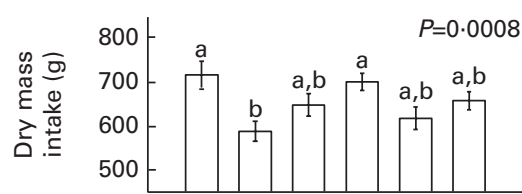

(C)

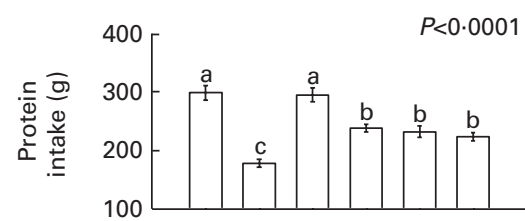

(D)

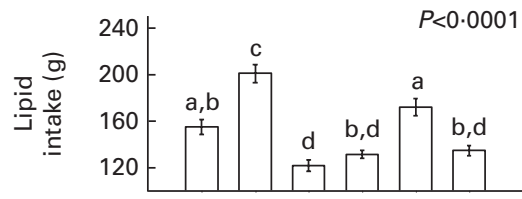

(E)

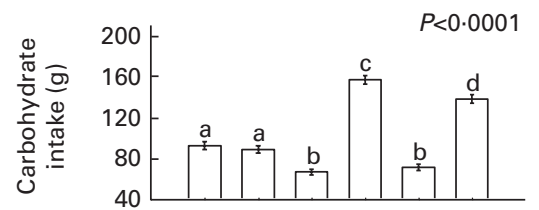

(F)

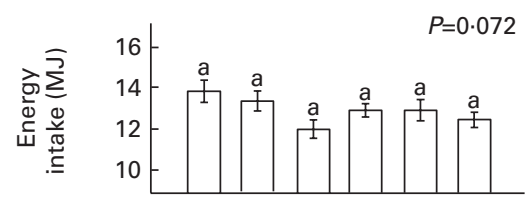

$(\mathrm{G})$

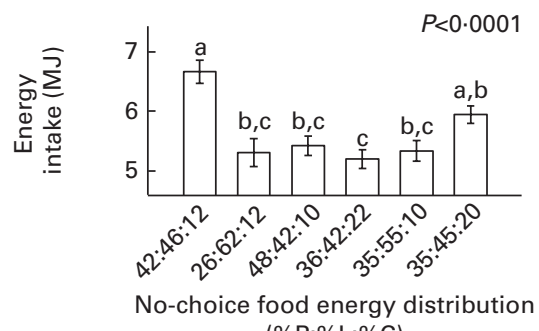

(\%P:\%L:\%C)

Fig. 1. Intake of (A) fresh mass, (B) dry mass, (C) digestible protein, (D) digestible lipid, (E) digestible carbohydrate and (F) metabolisable energy during the no-choice feeding period and of $(\mathrm{G})$ metabolisable energy during the choice feeding period. Values are means, with standard errors represented by vertical bars. The $P$ values are from ANCOVA tests across dietary treatments with mink mass as the covariate. ${ }^{a, b, c, d}$ Mean values with unlike letters were significantly different $(P<0.05$; Tukey-Kramer tests). \% , percentage protein; \%L, percentage lipid; \%C, percentage carbohydrate.

treatments $\left(R^{2} 0 \cdot 11, P=0 \cdot 0002\right)$, which justifies controlling for mink weight when comparing feeding responses. During the period of restriction to single foods, the intake of total fresh mass (Fig. 1(A)), dry mass (Fig. 1(B)), protein (Fig. 1(C)), lipid (Fig. 1(D)) and carbohydrate (Fig. 1(E)) differed significantly across dietary treatments $(P<0 \cdot 001)$, while differences in the intake of metabolisable energy were close to statistical significance $(P=0.072$; Fig. $1(\mathrm{~F}))$.

On plotting protein $v$. non-protein macronutrient (lipid plus carbohydrate) intake on a mass basis, the diet-specific intake points were found to exhibit no apparent pattern across dietary treatments (Fig. 2(A)). However, on plotting the intake of metabolisable energy from protein $v$. non-protein macronutrients, a clearer pattern was observed (Fig. 2(B)). First of all, the protein $v$. non-protein energy intake in mink restricted to three of the single foods $(35: 55: 10,35: 45: 20$ or $36: 42: 22)$ converged to the same point in nutrient space (Fig. 2(B)). When plotting the regulated intake point over $7 \mathrm{~d}$ of feeding in a previous study in $\operatorname{mink}^{(12)}$, it was found to coincide with the protein $v$. non-protein energy intake in mink restricted to these three diets (Fig. 2(B)).
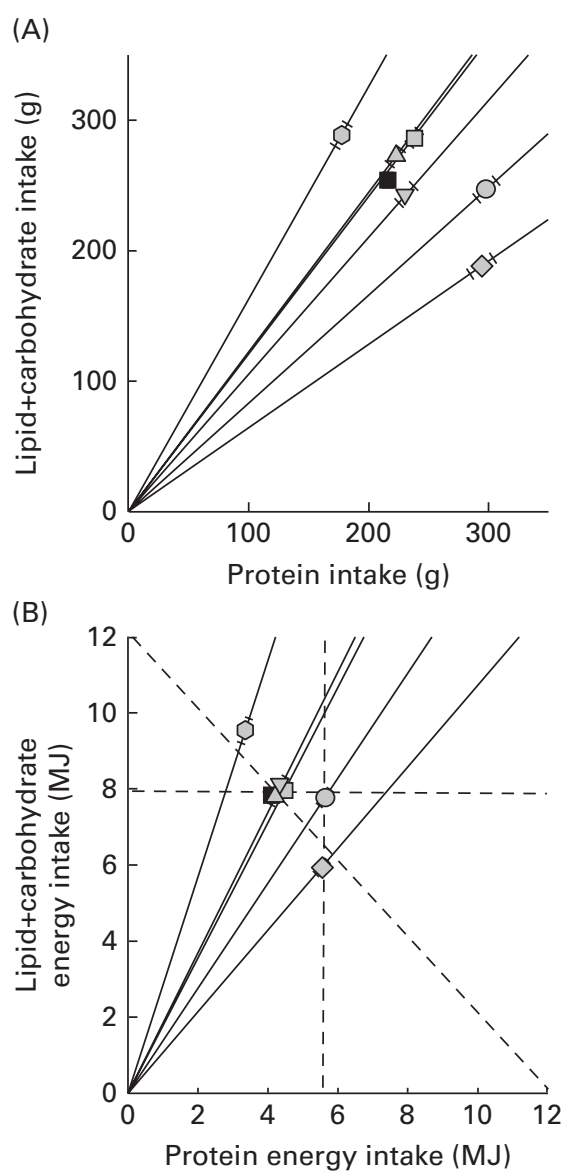

Fig. 2. Intake of (A) digestible protein $v$. non-protein macronutrients (lipid plus carbohydrate) and (B) metabolisable energy from protein $v$. non-protein macronutrients during the $7 \mathrm{~d}$ no-choice feeding period in mink restricted to one of the six diets. As the protein $v$. non-protein energy content is equal in the 35:55:10 food $(\nabla)$ and the 35:45:20 food $(\triangle)$, there are only five slopes in (B). The intake target is indicated by the regulated intake point $(\square)$ over the first $7 \mathrm{~d}$ of feeding for mink given choice in Mayntz et al. ${ }^{(12)}$, excluding the choice group that was nutritionally restrained from attaining this intake. Broken lines indicate equal ingestion of metabolisable energy from protein (vertical), non-protein macronutrients (horizontal), or protein plus non-protein macronutrients (slope of -1 ). Values are means, with standard errors represented by bars following the slopes. $0,42: 46: 12$ Food; $\bigcirc, 26: 62: 12$ food; $\diamond, 48: 42: 10$ food; $\square, 36: 42: 22$ food. Food composition is given as percentage protein:percentage lipid:percentage carbohydrate based on energy contents. 

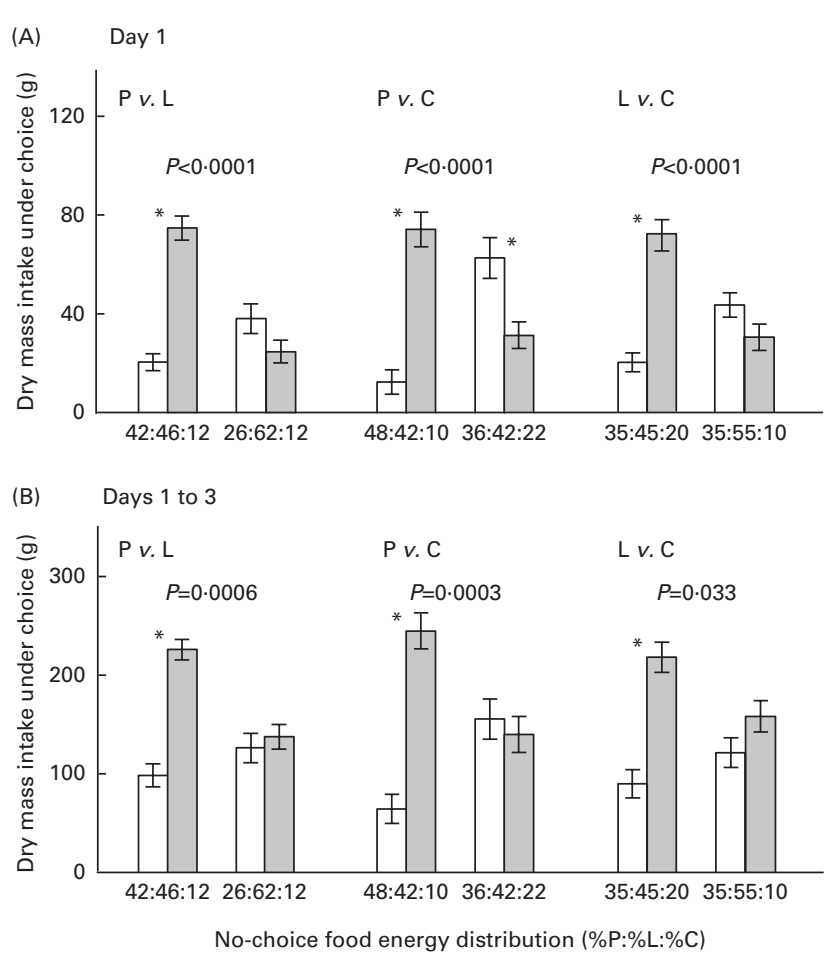

Fig. 3. Intake from each of the two foods in the three food pairings during $(A)$ the 1 st day and $(B)$ all the $3 \mathrm{~d}$ of choice feeding in mink after $7 \mathrm{~d}$ of restriction to single no-choice foods. Within each food pair, white bars represent consumption from the food presented as no-choice food to the left and grey bars represent consumption from the food presented as no-choice food to the right on the figure. Values are means, with standard errors represented by vertical bars. The $P$ values indicate significant differences in food selection between the mink provided with either of the two no-choice foods before choice feeding within each food pair using multivariate ANOVA tests. * Significant difference in selection between the two choice foods within mink that had been restricted to the same no-choice food $(P<0.05$; paired $t$ test). \%P, percentage protein; $\%$ L, percentage lipid; \%C, percentage carbohydrate.

When restricted to the high-lipid food (26:62:12), the mink overingested non-protein energy to a point where the surplus was slightly greater than the deficit of protein energy ingested relative to the regulated intake point (Fig. 2(B)). In contrast, mink restricted to the food with a moderate excess of protein (42:46:12) were able to achieve their presumed target intake for non-protein energy while overingesting protein (Fig. 2(B)). Mink that were restricted to the food with the highest excess of protein (48:42:10), however, ingested an amount of protein similar to that ingested by mink restricted to the 42:46:12 food at the consequence of attaining a considerably lower intake of non-protein energy (Fig. 2(B)).

\section{Regulation under choice}

When given a choice between two foods after restriction to a single food, energy intake was found to differ significantly across dietary treatments $(P<0 \cdot 0001$; Fig. $1(\mathrm{G}))$. This reflects that food selection was significantly affected by the macronutrient composition of the previous no-choice diet, both during the 1st day $(P<0 \cdot 0001 ;$ Fig. 3(A) $)$ and during all the $3 \mathrm{~d}(P<0.05$; Fig. 3(B)) of choice feeding. Within each of the three food pairings, we found asymmetric preference patterns during the choice feeding period. Mink provided one of the two foods during the no-choice feeding period (42:46:12, 48:42:10 or 35:45:20) consumed significantly larger $(P<0.0005)$ amounts of the nutritionally complementary food during the choice feeding period, whereas mink that had been restricted to the other food during the no-choice feeding period (26:62:12, 36:42:22 or 35:55:10) did not consume significantly different amounts $(P>0 \cdot 2)$ of the two foods (Fig. 3(B)). Mink that had been restricted to one of the two foods in each food pair thus showed a strong subsequent preference for the nutritionally complementary food, whereas mink that had been restricted to the other food in the food pair did not.

Within the two food pairings in which protein levels varied, mink that had been restricted to a high-protein, but low-lipid or low-carbohydrate food (42:46:12 or 48:42:10) consumed significantly larger amounts of the complementary food containing more lipid or carbohydrate but less protein (26:62:12 and $36: 42: 22$, respectively) throughout the choice feeding period $(P<0 \cdot 0001$; Fig. 3(B)). The intake trajectory of these mink thus closely followed the maximum limitation of lipid (Fig. 4(A)) or carbohydrate (Fig. 4(B)) within the nutritional span of the two choice foods. Similarly, mink that had been restricted to a high-carbohydrate, but low-lipid food (35:45:20) consumed significantly larger amounts of the complementary high-lipid, low-carbohydrate food (35:55:10) during the choice feeding period ( $P=0.0003$; Fig. 3(B)). The intake trajectory thus closely followed the nutrient composition of the 35:55:10 food, although diverging during the 2 nd day of choice feeding (Fig. 4(C)).

Mink that had been restricted to high-lipid foods (26:62:12 or $35: 55: 10$ ), in contrast, did not consume significantly different amounts of the two foods provided during the choice feeding period $(P>0.2 ;$ Fig. 3$)$, and the intake trajectories of these mink therefore passed midway between the nutrient compositions of their choice foods (Fig. 4(A) and (C)). Mink that had been restricted to the high-carbohydrate, but low-protein food (36:42:22) significantly selected the complementary highprotein, low-carbohydrate food (48:42:10) during the 1st day of choice feeding $(P=0.027$; Fig. $3(\mathrm{~A})$ ), but did not maintain this preference throughout the choice feeding period ( $P=0.68$; Fig. 3(B)). The intake trajectory of these mink therefore followed the nutrient composition of the 48:42:10 food during the 1st day of choice feeding only, and overall nutrient intake during the choice feeding period was intermediate between the nutrient compositions of the choice foods (Fig. 4(B)).

\section{Discussion}

Predatory animals have traditionally been believed to be prey limited. In addition, prey has generally been assumed to be a nutritionally balanced food source and predators would therefore not require mechanisms to balance the intake of specific nutrients ${ }^{(17,18,37)}$. More recently, a number of predators have been shown to balance their nutrient intake ${ }^{(11-16)}$. Compensatory feeding for specific nutrients after ingestion of nutritionally imbalanced food has been demonstrated in invertebrate predators ${ }^{(10)}$ and has recently been demonstrated during sequential assays of single foods in cats ${ }^{(13)}$. The results of the present study show that mink will select food that compensates for the nutritional imbalances imposed during a 
(A)

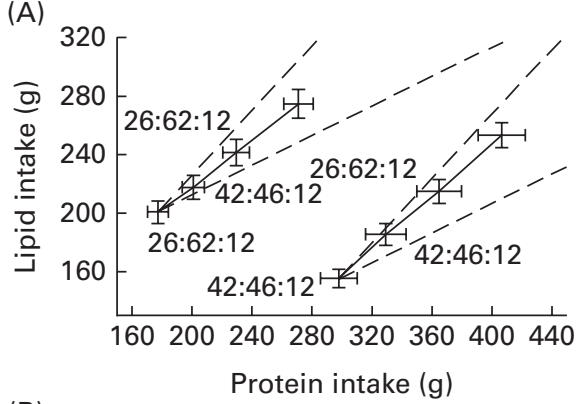

(B)

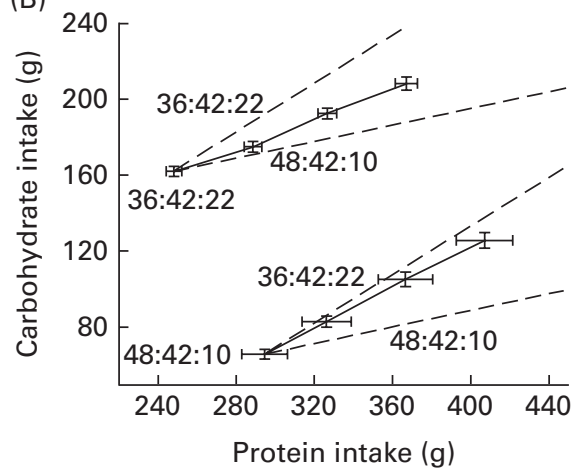

(C)

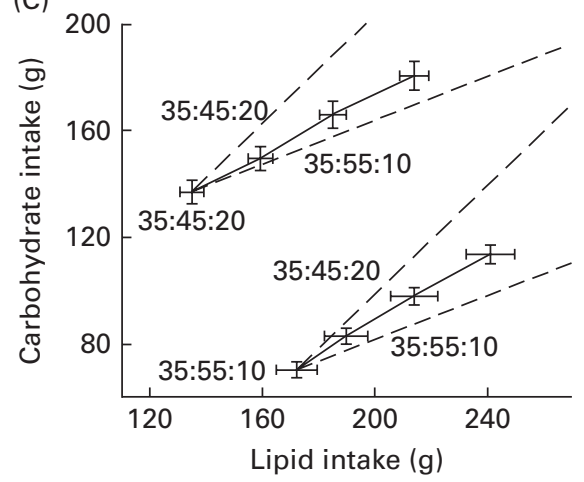

Fig. 4. Intake trajectories (solid lines) connecting the cumulative intake of specific digestible macronutrients from the end of the $7 \mathrm{~d}$ no-choice feeding period and during each of the three subsequent days of choice feeding. Values are means, with standard errors represented by horizontal and vertical bars. The slopes of the dashed lines show the nutrient ratios of the two provided choice foods. The area spanned by these lines indicates the overall nutritional intake composition that was available to the mink during the choice feeding period. (A) Protein $v$. lipid intake (fixed carbohydrate). (B) Protein $v$. carbohydrate intake (fixed lipid). (C) Lipid $v$. carbohydrate intake (fixed protein). Food composition is given as percentage protein:percentage lipid: percentage carbohydrate based on energy contents.

period of restriction to a nutritionally imbalanced food. Such intake regulation reflects balancing of requirements for amino acids from protein with requirements for energy primarily from non-protein macronutrients ${ }^{(38)}$. Interestingly, compensatory feeding also involved carbohydrate, which is generally not considered to be an important macronutrient in the diet of obligate carnivores ${ }^{(32)}$.

\section{Regulation under no-choice}

In the present study, the mink clearly did not regulate their intake of fresh or dry mass (Fig. 1(A) and (B)) or any individual macronutrient (Fig. 1(C)-(E)) to a constant intake level across dietary treatments when restricted to a single food, while energy intake did not differ significantly across dietary treatments (Fig. 1(F)). Similar energy intake across dietary treatments indicates that the mink regulated their total energy intake to a specific level, but it does not discount the alternative hypothesis that they balanced excesses and deficits of macronutrientspecific energy sources ${ }^{(39)}$. As we varied both carbohydrate and lipid contents in addition to protein content in the foods, pronounced differences were observed when comparing the mass and the energy relationships of the non-protein $v$. the protein component across dietary treatments (Fig. 2(A) and (B)). Therefore, using different combinations of carbohydrate $v$. lipid as the non-protein energy source across the foods allows us to establish that the mink did not regulate their intake on the basis of protein $v$. non-protein mass ingested (Fig. 2(A)), and instead strongly suggests that they balanced their intake of protein $v$. non-protein energy (Fig. 2(B)).

Protein $v$. non-protein energy intake in mink restricted to the 42:46:12 food with a moderate excess of protein did not align on a negative diagonal like the intake in mink restricted to the other foods (Fig. 2(B)). Instead, it aligned with the nonprotein energy coordinate of the proposed intake target (Fig. 2(B)). Protein intake in mink restricted to the food with the most extreme surplus of protein (48:42:10), however, aligned with the protein intake in mink restricted to the 42:46:12 food, suggesting a limit to the protein ingestion capacity at this intake level. A similar limit to protein intake is typically observed in omnivorous animals ${ }^{(1,3,5,7,9)}$, whereas some predators have been found willing to overingest large amounts of protein to increase their overall energy intake $^{(14,15)}$. However, these predators did not overingest protein extensively over the short term, but only when foods were consistently protein rich over a longer term, and a longer-term experiment would therefore be necessary to conclusively determine whether mink continue maintaining a limited protein intake if foods are consistently protein rich. Such phenotypic adaptation could occur as a gradual metabolic adjustment to cope with excessive amounts of amino acids and the load of ammonia and urea thus generated ${ }^{(40)}$

\section{Regulation under choice}

The asymmetric pattern of food preference depending on the no-choice diet within each food pair strongly indicates that the mink foraged to rebalance their intake of specific macronutrients (Fig. 3), rather than due to a preference for a more novel taste. It has been reported that many animals, including cats and $\operatorname{dogs}{ }^{(41)}$, show a preference for novel foods when in a state of nutritional imbalance. As we ensured that the mink had access to both foods in their food pair before the no-choice feeding period, the likelihood of them preferring the nutritionally complementary food based on novelty was reduced. Nevertheless, there is the possibility that sensoryspecific satiety may have contributed to the pattern of food selection $^{(42,43)}$. Selection of the complementary food may thus in part have been driven by the fact that this food represented a change from the food available in the previous no-choice feeding period. Sensory-specific satiety, however, does not 
appear to represent true nutrient-specific regulation based on nutritional feedback mechanisms ${ }^{(36,44)}$, and the role of this mechanism in nutrient balancing is therefore unclear.

In addition to balancing their intake of protein and lipid ${ }^{(12)}$, the mink regulated their intake of carbohydrate in the present study. Indeed, the growth of mink kits during lactation is faster when their mothers are provided a diet containing equal amounts of energy from carbohydrate and protein (protein: carbohydrate 34:33) relative to a diet high in protein (protein: carbohydrate $65: 3)^{(45)}$. Mink that were restricted to a highprotein diet in the present study (42:46:12 or $48: 42: 10$ ) correspondingly showed a strong preference for the complementary high-lipid or high-carbohydrate food (26:62:12 and 36:42:22, respectively) when given a choice (Fig. 3), indicating that there are costs associated with attaining higher amounts of metabolic energy from protein than required. However, when restricted to a high-carbohydrate diet $(35: 45: 20$ or $36: 42: 22)$, the mink selectively ingested the complementary high-lipid food $(35: 55: 10)$ and initially the complementary high-protein food (48:42:10), indicating rebalancing of nutrients and a ceiling to carbohydrate intake similar to that found in cats ${ }^{(13)}$

The results of the present study indicate a strong preference for lipid to support the majority of the energetic requirements in mink. This is further supported by the fact that the mink did not show any significant preference for the high-carbohydrate food after restriction to a high-lipid food in the present study (Fig. 3). Most probably, Fink et al. ${ }^{(45)}$ would therefore have found a similar or higher increase in kit growth if they had substituted carbohydrate with lipid in their experiment. The finding that mink avoid high intake of protein is interesting because the natural prey of mink, small vertebrates, are protein-rich food sources ${ }^{(32)}$. At the same time, mink, similar to cats, have a physiological requirement for protein as metabolic energy and therefore must have a proportion of their energy contributed by protein ${ }^{(32)}$. The results of the present study indicate that protein intake in excess of this requirement, however, is a deterrent to mink and presumably costly. If the nutrient compositions of small vertebrate prey reported by Eisert ${ }^{(32)}$ are representative, mink in nature may therefore often be limited by the amount of non-protein energy that they can attain, especially in the form of lipid.

The choice of a high-lipid diet is similar to the case observed in $\operatorname{dogs}{ }^{(16)}$, whereas cats select a diet higher in protein $^{(13)}$. Laboratory cats, however, select a carbohydrate content similar to that in standard mink food ${ }^{(12,13)}$, although feral cats consume a diet containing very little carbohydrate ${ }^{(46)}$. As the natural prey of mink is also rich in protein but contains limited amounts of carbohydrate ${ }^{(32)}$, mink in nature would likely be ecologically constrained from attaining a composition of protein and carbohydrate the same as that selected in the present study. Whether this choice in mink and cats could be an adaptive response to domestication and associated rearing diets and whether wild-caught mink and cats would show similar preferences remain to be investigated. When comparing digestion in farmed and feral American mink, farmed mink were found to exhibit a tendency towards higher digestibility of both carbohydrate and lipid and more efficient retention of nitrogen ${ }^{(47)}$, and in arctic foxes (Alopex lagopus), carbohydrate digestion was found to be significantly higher in farmed individuals than in wild individuals ${ }^{(48)}$. The results of the present study support the hypothesis that farmed or domesticated carnivores have adapted (phenotypically and/or genetically) to attain a more omnivorous gastrointestinal function and nitrogen metabolism in response to domesticated foods with high carbohydrate and low protein contents relative to their natural diets ${ }^{(12,48)}$. Genetic adaptations to a carbohydrate-rich diet might theoretically have evolved at a rapid rate during artificial selection of better-performing animals by the farmers.

\section{Conclusions}

The results of the present study show that American farmed mink balance their intake of protein $v$. non-protein energy when restricted to imbalanced diets and that they will compensate for a period of nutritional imbalance by subsequently selecting a nutritionally complementary diet. This demonstration of compensatory feeding for specific nutrients in a mammalian carnivore adds to the recent evidence that predators forage to balance their intake of specific nutrients rather than merely to meet their energetic requirements. Furthermore, the results show that carbohydrate intake is regulated in addition to lipid and protein intake.

\section{Acknowledgements}

The authors thank Mogens Olesen for providing technical assistance. The study was supported by a grant to D. M. from the Danish Research Council. S. J. S. was in receipt of a Federation Fellowship and is currently in receipt of a Laureate Fellowship from the Australian Research Council. J. H. was funded by the Natural Environment Research Council and a University Royal Society Fellowship. D. M. and V. H. N. conceived and designed the study. K. J. carried out the study. K. J., D. M., D. R. and S. J. S. analysed the data. K. J., D. M., D. R., S. J. S. and J. H. wrote the manuscript. All authors read and approved the final manuscript. None of the authors has any financial or other interests concerning the outcomes of the investigation or any conflicts of interest to declare.

\section{References}

1. Simpson SJ \& Raubenheimer D (1997) Geometric analysis of macronutrient selection in the rat. Appetite 28, 201-213.

2. Simpson SJ, Sibly RM, Lee KP, et al. (2004) Optimal foraging when regulating intake of multiple nutrients. Anim Behav 68, 1299-1311.

3. Raubenheimer D \& Jones SA (2006) Nutritional imbalance in an extreme generalist omnivore: tolerance and recovery through complementary food selection. Anim Behav 71, 1253-1262.

4. Forbes JM (2007) Voluntary Food Intake and Diet Selection in Farm Animals. Wallingford: CABI.

5. Sørensen A, Mayntz D, Raubenheimer D, et al. (2008) Protein-leverage in mice: the geometry of macronutrient 
balancing and consequences for fat deposition. Obesity 16, 566-571.

6. Behmer ST (2009) Insect herbivore nutrient regulation. Annu Rev Entomol 54, 165-187.

7. Felton AM, Felton A, Raubenheimer D, et al. (2009) Protein content of diets dictates the daily energy intake of a freeranging primate. Behav Ecol 20, 685-690.

8. Rothman JM, Raubenheimer D \& Chapman CA (2011) Nutritional geometry: gorillas prioritize non-protein energy while consuming surplus protein. Biol Lett 7, 847-849.

9. Jensen K, Engelke S, Simpson SJ, et al. (2013) Balancing of specific nutrients and subsequent growth and body composition in the slug Arion lusitanicus. Physiol Behav 122, 84-92.

10. Mayntz D, Raubenheimer D, Salomon M, et al. (2005) Nutrient-specific foraging in invertebrate predators. Science 307, 111-113.

11. Raubenheimer D, Mayntz D, Simpson SJ, et al. (2007) Nutrient-specific compensation following diapause in a predator: implications for intraguild predation. Ecology 88, 2598-2608.

12. Mayntz D, Nielsen VH, Sørensen A, et al. (2009) Balancing of protein and lipid intake by a mammalian carnivore, the mink, Mustela vison. Anim Behav 77, 349-355.

13. Hewson-Hughes AK, Hewson-Hughes VL, Miller AT, et al. (2011) Geometric analysis of macronutrient selection in the adult domestic cat, Felis catus. J Exp Biol 214, 1039-1051.

14. Jensen K, Mayntz D, Toft S, et al. (2011) Nutrient regulation in a predator, the wolf spider Pardosa prativaga. Anim Behav 81, 993-999.

15. Jensen K, Mayntz D, Toft S, et al. (2012) Optimal foraging for specific nutrients in predatory beetles. Proc $R$ SOC $B \mathbf{2 7 9}$, $2212-2218$

16. Hewson-Hughes AK, Hewson-Hughes VL, Colyer A, et al. (2013) Geometric analysis of macronutrient selection in breeds of the domestic dog, Canis lupus familiaris. Behav Ecol 24, 293-304.

17. Westoby M (1978) What are the biological bases of varied diets? Am Nat 112, 627-631.

18. Stephens DW \& Krebs JR (1986) Foraging Theory. Princeton, NJ: Princeton University Press.

19. Litzow MA, Piatt JF, Prichard AK, et al. (2002) Response of pigeon guillemots to variable abundance of high-lipid and low-lipid prey. Oecologia 132, 286-295.

20. Kitts DD, Huynh MD, Hu C, et al. (2004) Season variation in nutrient composition of Alaskan walleye pollock. Can J Zool 82, $1408-1415$.

21. Gende SM, Quinn TP \& Willson MF (2001) Consumption choice by bears feeding on salmon. Oecologia 127, 372-382.

22. Hauser DDW, Allen CS, Rich HB, et al. (2008) Resident harbor seals (Phoca vitulina) in Iliamna Lake, Alaska: summer diet and partial consumption of adult sockeye salmon (Oncorbynchus nerka). Aqua Mamm 34, 303-309.

23. Chen XL, Dickman CR \& Thompson MB (2004) Selective consumption by predators of different body regions of prey: is rate of energy intake important? J Zool 264, 189-196.

24. Herbers JM (1981) Time resources and laziness in animals. Oecologia 49, 252-262.

25. Jeschke JM (2007) When carnivores are "full and lazy". Oecologia 152, 357-364.

26. Sánchez-Vázquez FJ, Yamamoto T, Akiyama T, et al. (1999) Macronutrient self-selection through demand-feeders in rainbow trout. Physiol Behav 66, 45-51.

27. Rubio VC, Sánchez-Vázquez FJ \& Madrid JA (2003) Macronutrient selection through postingestive signals in sea bass fed on gelatine capsules. Physiol Behav 78, 795-803.
28. Chanin PRF \& Linn I (1980) The diet of the feral mink (Mustela vison) in southwest Britain. J Zool 192, 205-223.

29. Brzezinski M \& Zurowski W (1992) Spring diet of the American mink Mustela vison in the Mazurian and Brodnica Lakelands, northern Poland. Acta Theriol 37, 193-198.

30. Jedrzejewska B, Sidorovich VE, Pikulik MM, et al. (2001) Feeding habits of the otter and the American mink in Białowieza Primeval Forest (Poland) compared to other Eurasian populations. Ecography 24, 165-180.

31. Hammershøj M, Thomsen EA \& Madsen AB (2004) Diet of free-ranging American mink and European polecat in Denmark. Acta Theriol 49, 337-347.

32. Eisert R (2011) Hypercarnivory and the brain: protein requirements of cats reconsidered. J Comp Physiol B 181, 1-17.

33. Morifuji M, Sakai K, Sanbongi C, et al. (2005) Dietary whey protein increases liver and skeletal muscle glycogen levels in exercise-trained rats. Br J Nutr 93, 439-445.

34. Martin GJW \& Rand JS (1999) Food intake and blood glucose in normal and diabetic cats fed ad libitum. J Feline Med Surg $\mathbf{1}$, $241-251$

35. Raubenheimer D \& Rothman JM (2013) Nutritional ecology of entomophagy in humans and other primates. Annu Rev Entomol 58, 141-160.

36. Simpson SJ \& Raubenheimer D (2012) The Nature of Nutrition: A Unifying Framework from Animal Adaptation to Human Obesity. Princeton, NJ: Princeton University Press.

37. Galef BG (1996) Food selection: problems in understanding how we choose foods to eat. Neurosci Biobehav Rev 20, 67-73.

38. Johnson CA, Raubenheimer D, Rothman JM, et al. (2013) 30 Days in the life: daily nutrient balancing in a wild chacma baboon. PLOS ONE 8, e70383.

39. Raubenheimer D \& Simpson SJ (2003) Nutrient balancing in grasshoppers: behavioural and physiological correlates of dietary breadth. J Exp Biol 206, 1669-1681.

40. Azzout-Marniche D, Gaudichon C, Blouet C, et al. (2007) Liver glyconeogenesis: a pathway to cope with postprandial amino acid excess in high-protein fed rats? Am J Physiol Regul Integr Comp Physiol 292, R1400-R1407.

41. Bradshaw JWS (2006) The evolutionary basis for the feeding behavior of domestic dogs (Canis familiaris) and cats (Felis catus). J Nutr 136, 1927S-1931S

42. Rolls BJ, Rolls ET, Rowe EA, et al. (1981) Sensory specific satiety in man. Physiol Behav 27, 137-142.

43. Birch LL \& Deysher M (1986) Caloric compensation and sensory specific satiety: evidence for self regulation of food intake by young children. Appetite 7, 323-331.

44. Raynor HA \& Epstein LH (2001) Dietary variety, energy regulation, and obesity. Psychol Bull 127, 325-341.

45. Fink R, Tauson A-H, Chwalibog A, et al. (2004) Effects of substitution of dietary protein with carbohydrate on lactation performance in the mink (Mustela vison). J Anim Feed Sci 13, 647-664.

46. Plantinga EA, Bosch G \& Hendriks WH (2011) Estimation of the dietary nutrient profile of free-roaming feral cats: possible implications for nutrition of domestic cats. Br J Nutr 106, S35-S48

47. Gugołek A, Zalewski D, Strychalski J, et al. (2013) Food transit time, nutrient digestibility and nitrogen retention in farmed and feral American mink (Neovison vison) - a comparative analysis. J Anim Physiol Anim Nutr 97, 1030-1035.

48. Ahlstrøm $\varnothing$, Fuglei E \& Mydlanda LT (2003) Comparative nutrient digestibility of arctic foxes (Alopex lagopus) on Svalbard and farm-raised blue foxes (Alopex lagopus) Comp Biochem Physiol 134, 63-68. 